\title{
Analisis Kointegrasi Bursa Efek Indonesia, Malaysia dan Singapura: Pendekatan Pair-Case dan Multivariate
}

\author{
Amsal Irmalis*, Fajri Hadi \\ ${ }^{1}$ Fakultas Ekonomi, Universitas Teuku Umar, Indonesia \\ *amsal.irmalis@utu.ac.id
}

\begin{abstract}
This study aims to examine the stock market cointegration between Indonesia Stock Exchange (IDX), Malaysian Stock Exchange (Bursa Malaysia) and Singapore Stock Exchange (SGX). The weekly stock indexes covering January 2013 to December 2018 are analyzed using the Johansen testing approach with the Vectorautoregresiv (VAR) framework. This study uses a pair-case and multivariate manner. The results show that multivariate analysis does not show any cointegration between Indonesia, Malaysia, and the Singapore Stock Exchange. However, cointegration exists between the Malaysian and Singapore capital markets. These results confirm that the same results of bivariate analysis do not always support multivariate testing.
\end{abstract}

Keywords: Cointegration, Diversification, Multivariate, Pair-case

\section{PENDAHULUAN}

Perkembangan pasar keuangan internasional dalam beberapa dekade terakhir telah ditandai oleh banyak perubahan kebijakan mengenai pembatasan transaksi lintas batas, investasi, dan kontrol nilai tukar. Banyak batasan yang dibuat yang telah dihilangkan dan mengarah pada reformasi yang kuat dari struktur pasar modal internasional. Bursa saham nasional seperti Bursa Efek Indonesia (BEI) diminati oleh banyak investor asing yang mencari tingkat pengembalian dan diversifikasi yang lebih baik untuk mengurangi risiko portofolio mereka. Internasionalisasi pasar keuangan seperti ini telah menyebabkan sejumlah penelitian berfokus pada manfaat liberalisasi operasi keuangan internasional. Sedangkan manfaat dari diversifikasi telah disarankan oleh banyak penulis sebagai cara untuk pembagian risiko yang optimal, namun beberapa penelitian menunjukkan sudut pandang negatif tentang masalah ini. Selain peerkembangan keuangan internasional yang semakin tak berbatas, situasi keuangan suatu negara seperti Indonesia, Malaysia dan Singapura sangat dipengaruhi oleh kondisi ekonomi dunia. Saat ini, negara-negara khusunya di kawasan Asia Tenggara sangat bergantung pada investasi-investasi negara pemodal seperti Amerika dan Cina maupun investasi yang didapatkan dari kerjasama antar negara ASEAN, yang berarti kondisi perekonomian negara-negara maju dan negara-negara yang ada di kawasan yang sama mempunyai pengaruh yang besar terhadap satu sama lain. Dengan demikian tidak heran jika pergerakan IHSG dan indeksindeks lainnya di ASEAN seperti Bursa Malaysia dan Singapore Stock Index (SGX) mengikuti pergerakan indeks bursa saham negara maju dan juga dipengaruhi oleh bursa saham negara ASEAN lainnya. Investor yang berinvestasi baik secara local maupun internasional akan menerima imbas dari perubahan-perubahan yang diakibatkan oleh 
kondisi ekonomi dunia yan terdiri dari ekonomi negara-negara maju dan kawasan. Semakin tinggi pengaruhnya maka portofolio investasi akan terekspos terhadap risiko yang semakin tidak menentu. Indonesia, Malaysia dan Singapura merupakan 3 ekonomi terbesar di Asia Tenggara yang memiliki peran yang sangat penting dan memiliki sejarah yang sangat panjang dalam kawasan tersebut, Sehingga penelitian ini memfokuskan melihat kointegrasi antara ketiga negara tersebut.

Istilah co-movement, integrasi dan kointegrasi sering sekali dibahas dalam literatur-literatur terkait hubungan jangka panjang dan pendek, ditambah lagi dengan semakin terintegrasinya pasar keuangan dunia. Istilah tersebut dikaitkan untuk menjelaskan hubungan jangka pendek dan jangka panjang antara dua atau lebih ekuitas/saham dan bahkan indeks saham. Termasuk variabel-variabel ekonomi seperti, nilai tukar, suku bunga, GDP, inflasi dan lainlain.

Penelitian ini menekankan pada pendekatan kointegrasi yang digunakan untuk mengidentifikasi hubungan jangka panjang dari indeks harga saham gabungan Indonesia, Malaysia dan Singapura. Kointegrasi adalah sebuah konsep stationeritas dan urutan integrasi dari sebuah series data (Brooks, 2008).

Dalam studi tentang volatilitas dan hubungan jangka panjang antara pasar saham internasional, Lanouar (2009) tidak menemukan asosiasi hubungan jangka panjang (kointegrasi) antara Indeks Saham Islam dan konvensional. Assidenou (2011) berpendapat bahwa investor lokal di pasar modal Asia tidak dapat menghindari pengaruh dari pasar modal luar. Quang (2007) menganalisis dan menemukan adanya kointegrasi antara saham-saham yang ada di Bursa Saham Republik Ceko. Claire \& Mcmanus (2002) menemukan bahwa tidak ada hubungan jangka panjang antara pasar modal US dan pasar Eropa, Sehingga memudahkan investor dari US untuk mendapatkan keuntungan diversifikasi internasional dari berinvestasi pada negara Eropa terutama pasar modal Hungaria dan
Polandia. Kemudian berbeda dengan Introvigne (2017) yang melakukan uji kointegrasi Fine dan Non-Fine Wine Index dengan uji Engle-Granger serta Johansen Test dan menemukan bahwa sebaiknya Wine Stock harus dimasukkan ke dalam portofolio investasi mengingat tidak adanya kointegrasi. Walid (2021) menemukan ketergantungan atau interdepenedsi antar indeks sektoral Qatar Exchange, sehingga shock pada satu indeks saham akan mempengaruhi indeks lainnya. Kemudian, bursa saham juga tidak hanya dipengaruhi oleh bursa saham lainnya, tapi juga oleh variabel ekonomi seperti yang dikemukan oleh Bhuvaneshwari \& Ramya (2017) bahwa terdapat korelasi yang signifikan antara saham dan nilai tukar. Berbagai penelitian terkait kointegrasi pasar saham dari Indonesia seperti Musnadi (2019), Muhajir (2008), menunjukkan tidak adanya kointegrasi antara indeks-indeks saham di Bursa Efek Indonesia, namun ada juga penelian terdahulu oleh Danuprata (2003) yang menemukan co-movement antar indeks harga saham di Indonesia.

Dalam penelitian ini akan diuji pergerakan harga saham pada indeks saham Indonesia, Malaysia dan Singapura, yaitu untuk mencari efek dari perubahan pada salah satu indeks harga saham yang mempengaruhi harga indeks saham pada dua negara lainnya secara pair-case maupun multivariat. Untuk mencari bukti perubahan harga dalam satu pasar terhadap harga pada pasar lainnya maka harus di uji dalam bentuk hubungan keseimbangan antar indeks harga saham dalam jangka panjang (Pizzi et al, 1997). Jika ditemukan adanya hubungan tersebut maka sebaiknya investor tidak memasukkan sekuritas-sekuritas tersebut dalam portofolionya dikarenakan tidak akan mendapatkan keuntungan dari strategi diversifikasi, sebaliknya investor harus memasukkan sekuritas-sekuritas yang tidak saling berkointegrasi sehingga mampu mendapatkan keuntungan dari strategi diversifikasi tersebut. Analisis kointegrasi multivariat yang dilakukan adalah berdasarkan analisis yang pernah dilakukan oleh Mills \& Millss (1991) dalam menganalisi 
pergerakan harga-harga obligasi secara bersamaan. Clare et al (1995) melakukan analisis kointegrasi international bond secara pair-case atau berpasangan.

Metode-metode ini kemudian di adopsi oleh banyak peneliti dalam melihat kointegrasi indeks saham secara multivariate dan pair-case. Sehingga, banyak peneliti yang melakukan tes kointegrasi antara dua indeks saham (pair-case) dan lebih dari dua (multivariate), pada umumnya hasil yang ditunjukkan oleh analisis pair-case dan multivariate umumnya sama seperti Lanouar (2009) Musnadi et al (2019) Muhajir (2012 dan Quang (2007). Kebaharuan (novelty) dari penelitian ini adalah dari hasil penelitian ini membuktikan bahwa analisis multivariat dan pair-case (berpasangan) tidak selamanya menunjukkan hasil yang sama.

Dalam sejarah bursa saham tercatat pada Agustus 2018 Bursa Indonesia menunjukkan penurunan angka IHSG 3,55\%. Pada bulan yang sama indeks harga saham lainnya di Asia Seperti Indeks SET (Thailand) juga menunjukkan penurunan $0.96 \%$,indeks KLCI (Malaysia) turun 1,24\%, indeks Strait Times turun $0,97 \%$, Indeks Nikkei turun $1,98 \%$, Indeks Shanghai turun 0,32\%, Indeks Hang Seng turun 1,52\%. Kecenderungan penurunan yang terjadi hampir apada semua bursa di Asia seolah memberikan signal bahwa bursa saham yang ada dalam kawasan yang sama bisa saja terpengaruh oleh faktorfaktor ekonomi baik dari faktor internal maupun eksternal. Faktor -faktor tersebut antara lain corporate cction, proyeksi kinerja masa depan, kebijakan pemerintah, fluktuasi kurs, kondisi fundamental ekonomi makro, rumor dan sentimen pasar serta faktor manipulasi pasar dan kepanikan.

Bahkan terkadang efek perubahan kondisi ekonomi yang bukan berada pada kawasan yang sama juga sering mempengaruhi indeks saham pada kawasan lainnya. Misalnya pada saat kriris Turki pada agustus lalu juga memiliki efek pada emiten di negara Asian seperti Indonesia, dilansir oleh TEMPO bahwa pada saat kriris di Turki beberapa emiten di Indonesia melemah sampai pada titik 5\%. Sehingga dapat disimpulkan bahwa efek perubahan harga pada sebuah indeks pasar dari sebuah negara yang dipengaruhi oleh faktor-faktor ekonomi akan berdampak apada indeks pasar saham di negara lain baik pada kawasan yang sama maupun yang berbeda.

Adanya hubungan antar indeks saham secara internasional membuka peluang investasi bagi investor sekaligus terciptanya risiko akibat kondisi yang tidak baik dari negara luar. Akibatnya walaupun banyak investor yang berinvestasi pada saham lokal tidak menjamin akan aman dari pengaruh buruk dari kondisi ekonomi internasional.

Investor dapat melakukan international diversification dalam portofolio investasi mereka. Hal ini penting dalam menghadapi risiko yang berasal dari pasar saham internasional. Keuntungan dari strategi diversifikasi sangat tergantung dari korelasi return antar pasar saham. Korelasi yang rendah akan memberikan efek yang lemah terhadap pengurangan risiko. Namun, diversifikasi adalah sebuah pilihan, sehingga pengurangan risiko atau penambahan keuntungan bagi portofolio internasional sangat dipengaruhi oleh perilaku seorang investor. Diversifikasi tidak akan berhasil jika pasar saham saling berkointegrasi. Hal ini dikarenakan return pasar akan bergerak secara bersamaan dalam jangka panjang sehingga melakukan diversifikasi pada asset yang berbeda tidak akan mengurangi risiko. Musnadi et al (2018) menyebutkan bahwa pasar saham dunia akan semakin terintegrasi dikarenakan oleh perkembangan zaman dan technology, sehingga investor akan kesulitan memanfaatkan diversifikasi sebagai alat untuk mendapatkan abnormal return. Climent \& Meneu (2003) dalam hasil penelitiannya juga pasar modal dalam sebuah region yang sama cenderung memiliki pergerakan return yang sama sehingga integrasi akan tinggi.

Gerrits \& Yuce (1999) menguji kointegrasi antara harga saham di Inggris, Belanda, Jerman dan AS. Data yang digunakan adalah daily closing price harian untuk periode antara Maret 1990 dan Oktober 1994. Hasil penelitian ini menunjukkan 
bahwa bursa pasar US berpengaruh kuat terhadap bursa Inggris, Jerman dan Belanda. Selaian itu, ditemukan bahwa Bursa saham ketiga pasar Eropa tersebut saling mempengaruhi baik dalam jangka pendek maupun jangka panjang. Oleh karena itu, strategi diversifikasi di antara pasar saham tersebut tidak menghilangkan secara signifikan terhadap risiko portofolio.

Wong et al (2005) melakukan investigasi terhadap hubungan jangka panjang bursa saham India dengan bursa saham negara-negara maju antara lain bursa saham US, UK dan Jepang. Hasil temuan adalah bursa saham India terintegrasi dengan bursa saham negara maju dan sangat sensitif terhadap pergerakan return dari bursa tersebut. Namun, hasil temuan menunjukkan bahwa dalam jangka pendek bursa saham dari negara maju mempengaruhi bursa India tapi tidak sebaliknya.

Yang et al (2002) melakukan penelitian pada 10 emerging stock market di ASIA untuk melihat hubungan antar bursa saham selama periode krisis 1997-1998. Penelitian ini menemukan bukti bahwa bursa saham Asia memiliki hubungan jangka panjang. Bahkan pasar saham di ASIA akan menjadi lebih terintegrasi pada saat setelah menghadapi krisis dibandingkan sebelum krisis. Tingkat integrasi cenderung berubah dari waktu ke waktu.

Khan (2011) menemukan pasar Cina, Malaysia dan Australia tidak memiliki kointegrasi dengan bursa saham US. Terlebih lagi, ketiga bursa saham negara tersebut memiliki sensitivitas paling rendah terhadap pasar global, Sehingga memberikan peluang diversifikasi yang baik daripada negara lainnya. Alagidede (2008) meneliti integrasi pasar saham Afrika dengan seluruh dunia. Hasilnya menunjukkan bahwa pasar Afrika kurang terintegrasi dengan pasar global dan memiliki lebih banyak integrasi dengan masalah lokal seperti kebijakan politik dan ekonomi.

Puspitasari dkk (2015), menemukan pergerakan arah return saham yang mirip akan memberikan return dan risk yang hampir sama, sehingga tidak ada bedanya berinvestasi secara domestik ataupun pada pasar asing. Indonesia, Malaysia dan Singapura adalah triangle dalam perekonomian negara-negara Asia Tenggara. Ketiga negara tersebut adalah memiliki kekuatan yang paling besar diantara negara ASEAN lainnya. Kebijakan yang dibuat oleh policy maker bisa saja diutamakan untuk mendukung dan mempertahankan kondisi perekonomian kawasan. Kointegrasi pasar modal yang kuat akan menghilangkan abnormal return. Sehingga menjadi sangat penting bagi investor dalam melakukan research cointegration antar pasar modal sebelum membentuk portofolio investasi. Oleh karena itu, penelitian ini akan melihat kointegrasi antar pasar modal Indonesia, Malaysia dan Singapura.

Penelitian ini bertujuan untuk menginvestigasi hubungan jangka panjang atau kointegrasi bursa saham Indonesia, Malaysia dan Singapura. Pengujian akan dilakukan secara pair-case dan multivariate. Penelitian ini juga akan meneliti apakah hasil analisis secara multivariate akan memberikan hasil yang sama dengan analisis yang dilakukan secara berpasangan (pair-case). Adapun rumusan hipotesis penelitian ini adalah dijabarkan sebagai berikut:

Pengujian secara multivariat:

$\mathrm{H}_{0}$ : Tidak ada kointegrasi antara bursa saham Indonesia, Malaysia dan Singapura

$\mathrm{H}_{1}$ : Terdapat kointegrasi antara bursa saham Indonesia, Malaysia dan Singapura

Pengujian secara pair-case:

Indonesia dan Malaysia

$\mathrm{H}_{0}$ : Tidak ada kointegrasi antara bursa saham Indonesia dan Malaysia

$\mathrm{H}_{1}$ : Terdapat kointegrasi antara bursa saham Indonesia dan Malaysia

Indonesia dan Singapura

$\mathrm{H}_{0}$ : Tidak ada kointegrasi antara bursa saham Indonesia dan Singapura

$\mathrm{H}_{1}$ : Terdapat kointegrasi antara bursa saham Indonesia dan Singapura 
Malaysia dan Singapura

$\mathrm{H}_{0}$ : Tidak ada kointegrasi antara bursa saham Malaysia dan Singapura

$\mathrm{H}_{1}$ : Terdapat kointegrasi antara bursa saham Malaysia dan Singapura

\section{METODE}

Penelitian ini menggunakan data weekly closing price dari IHSG (^JKSE), STI $\left({ }^{\wedge} \mathrm{STI}\right)$ dan KLCI (^KLSE) dari Januari 2013 sampai Desember 2018 (5 Tahun). Data penelitian ini diperoleh dari website www.yahoofinance.com. Data yang telah di dapatkan kemudian di uji dengan Johansen Test. Metode Johansen merupakan salah satu metode yang banyak digunakan untuk melihat kontegrasi pasar saham.

\section{ADF Test dan Lag Optimal}

Cointegration test mensyaratkan bahwa series data harus non stationer. Untuk itu terlebih dahulu akan dilakukan stationarity test. Untuk itu, penelitian ini menggunakan ADF test. ADF test dilakukan Secara berkelompok dan berpasangan. Setelah itu, tahap selanjutnya adalah memilih lag optimal. Hal ini untuk melihat dan mengantisipasi kemungkinan kesalahan spesifikasi ketika lag yang dipilih terlalu rendah dan mengurangi tingkat kebebasan ketika lag yang dipilih terlalu panjang. AIC atau Akaike Information Criterion (AIC) dipilih untuk menentukan lag optimal.

\section{Johansen Test}

Setelah dua kondisi diatas telah terpenuhi, maka Johansen Test bisa dilakukan untuk melihat kointegrasi antar pasar saham. Kointegrasi dilihat secara pair-case antara pasar saham Indonesia Stock Exchange dengan Malaysian Stock Exchange; antara Indonesia Stock Exchange dan Singapore Stock Exchange dan Malaysian Stock Exchange dan Singapore Stock Exchange. Setelah itu, dilakukan Johansen Test secara berkelompok (Indonesia, Malaysia dan Singapore Stock Excnhage) secara bersamaan.

Variabel dengan unit-root akan persisten terhadap shock atau unexpected change, Sehingga apabila ada shock pada periode t tidak akan memberikan efek pada periode $\mathrm{t}+1$ atau $\mathrm{t}+2$ dan seterusnya. Oleh karena itu, kointegrasi test mensyaratkan series harus non-stationer atau stationer pada $\mathrm{I}(1)$.

Johansen test merupakan sebuah formula untuk mengestimasi sistem kointegrasi multivariat berdasarkan error correction model (VAR) (k) dengan Gaussian-error dan kegunaannya dalam analisis masalah konvergensi akan dijelaskan sebagai berikut:

Misalkan $Z_{t}$ adalah sebuah series variabel I (1) dari sebuah indeks harga saham. Maka modal VAR dari series tersebut adalah sepertu di bawah ini:

$$
\mathrm{Z}_{\mathrm{t}}=\mu+\mathrm{B}_{1} \mathrm{X}_{\mathrm{t}-1}+\mathrm{B}_{2} \mathrm{X}_{\mathrm{t}-2}+\ldots+\mathrm{B}_{\mathrm{k}} \mathrm{X}_{\mathrm{t}-\mathrm{k}}+\mathrm{et}
$$

Model diatas diformulasikan dalam bentuk model error correction model VAR :

$$
\Delta Z t=\mu+\sum_{i=1}^{k-1} D_{\mathrm{i}} \Delta X_{\mathrm{t}-1}+\mathrm{W}_{\mathrm{i}} \Delta \mathrm{X}_{\mathrm{t}-\mathrm{k}}+e
$$

Dimana $\Delta$ menandakan first difference, $D_{i}$ adalah matriks koefisien $\mathrm{n} \times \mathrm{n}$, didefinisikan sebagai $D_{i}=-\left(\mathrm{I}-\mathrm{B}_{1}-\ldots-\mathrm{B}_{\mathrm{i}}\right)$, yang mewakili dinamika jangka pendek, dan $\mathrm{P}$ adalah matriks $\mathrm{n} \times \mathrm{n}$ yang didefinisikan sebagai $\mathrm{W}_{\mathrm{i}}=-\left(\mathrm{I}-\mathrm{B}_{1}-\ldots-\mathrm{B}_{\mathrm{k}}\right)$, dimana I adalah matriks identitas, yang peringkatnya menentukan jumlah kointegrasi yang berbeda vektor. Kegunaan metodologi ini dalam analisis saat ini pada dasarnya untuk menentukan pangkat matriks $\mathrm{W}_{\mathrm{i}}$. Jika $\mathrm{W}$ memiliki peringkat $r$, lalu ada hubungan kointegrasi antara $\mathrm{Zt}$ or $\mathrm{n}-\mathrm{r}$ common trend stokastik. Jumlah vektor kointegrasi mengungkapkan luasnya integrasi di seluruh pasar saham. Jika $\mathrm{n}-\mathrm{r}=0(\mathrm{r}=\mathrm{n})$ (full rank), menunjukkan tidak adanya tren stokastik, dengan semua elemen di Zt stasioner [I (0)] maka uji kointegrasi tidak bisa dilakukan. Namun, apabila $\mathrm{n}-\mathrm{r}=\mathrm{n}(\mathrm{r}=0)$ maka kointegrasi dapat diidentifikasi karna tidak adanya stationaritas jangka panjang dari elemen elemen yang ada. 


\section{HASIL DAN PEMBAHASAN}

Gambar 1 menunjukkan pergerakan Indeks Harga Saham Pasar Modal Indonesia (JKSE), Malaysia (KLSE) Dan Singapura (STI) selama 312 minggu (2013-2018). Pada fase 100 minggu pertama harga indeks saham Indonesia dan Singapura terlihat sedikit meningkat, bahkan Indeks harga saham Malaysia menunjukkan peningkatan yang cukup tinggi. Sangat berbeda dengan fase 100 minggu kedua ketiga pasar modal mengindikasikan penurunan harga. Penurunan harga saham pada minggu kedua mungkin memiliki asosiasi dengan turunnya level harga minyak pada 100 minggu kedua dalam kurun waktu 2014-2015. Namun, Hal ini belum memperlihatkan apakah benar disebabkan oleh pergerakan harga minyak dunia atau masing-masing pasar saham saling mempengaruhi satu sama lain.

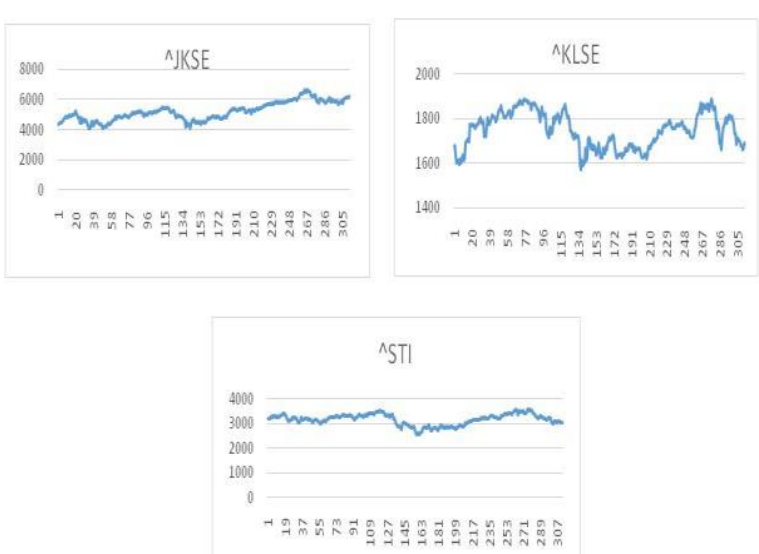

Gambar 1 : Harga Saham Mingguan 2013-2018

Tabel 1 memberikan bukti bahwa weekly return dari data series selama periode 2013 sampai 2018 dengan rata-rata 0,13\% (Indonesia) $\quad 0,01 \%$ (Malaysia) dan $0,00001.7 \%$ (Singapore). Hal ini menunjukkan rata-rata return mingguan dari ^JKSE lebih tinggi dari kedua pasar saham lainnya. Namun, sekuritas di pasar modal Indonesia memiliki tingkat risiko yang lebih tinggi $(0,22)$ dari pasar modal lainnya. Artinya Investor di Indonesia akan memiliki volatile return, yaitu kesempatan untuk mendapatkan return lebih baik namun peluang risiko yang lebih besar.
Tabel 1. Return Summary January 2013Desember 2018

\begin{tabular}{lrrr}
\hline $\begin{array}{l}\text { Descriptive } \\
\text { Statistics }\end{array}$ & Indonesia & Malaysia & Singapore \\
\hline $\begin{array}{l}\text { Mean } \\
\text { Standard }\end{array}$ & 0,001358 & 0,000117 & $-1,7 \mathrm{E}-05$ \\
Error & 0,001254 & 0,000732 & 0,000938 \\
Median & 0,003294 & 0,00084 & 0,001548 \\
Standard & & & \\
Deviation & 0,022107 & 0,012912 & 0,016548 \\
Sample & & & \\
Variance & 0,000489 & 0,000167 & 0,000274 \\
Kurtosis & 2,766679 & 2,305276 & 2,407487 \\
Skewness & $-0,20735$ & $-0,01847$ & 0,278292 \\
Range & 0,175027 & 0,098737 & 0,119514 \\
Minimum & $-0,09196$ & $-0,05101$ & $-0,046$ \\
Maximum & 0,083069 & 0,047728 & 0,073519 \\
Sum & 0,422209 & 0,036398 & $-0,00522$ \\
\hline
\end{tabular}

Sumber: Diolah

Pengujian stationeritas pada penelitian ini dilakukan dengan ADF test dan ditemukan bahwa semua series data adalah tidak stationer pada level 5\%. Namun, pengujian selanjutkan dilakukan pada firstdifference dan ditemukan bahwa semua data adalah stationer. Sehingga dapat disimpulkan bahwa data tersebut stationer pada firstdifference $\mathrm{I}(1)$. Tabel 2 di bawah ini menunjukkan hasil uji ADF :

Tabel 2. Hasil Tes Stationeritas

\begin{tabular}{lcccc}
\hline \multirow{2}{*}{$\begin{array}{c}\text { Unit-root } \\
\text { Testing }\end{array}$} & \multicolumn{2}{c}{$\mathrm{I}(0)$} & \multicolumn{2}{c}{$\mathrm{I}(1)$} \\
\cline { 2 - 5 }$($ ADF Test) & Statistic & Prob & Statistic & Prob \\
\hline ^JKSE & $-2,3388$ & 0,1605 & $-13,9714$ & 0,0000 \\
^KLSE & $-2,5754$ & 0,0992 & $-17,6573$ & 0,0000 \\
^STI & $-1,9997$ & 0,2870 & $-16,5531$ & 0,0000 \\
\hline
\end{tabular}

Sumber: Diolah

Dari tabel 2 diatas menampilkan nilai probability dan statistic series keseluruhan data berada pada level atau $\mathrm{I}(0)$, mengindikasikan data tidak stationer pada level 5\%. Namun, data stationer pada firstdifference atau I(1)-nya. Dalam kebanyakan kasus, jika dua variabel yang I(1) digabungkan secara linear, maka kombinasi variable juga akan menjadi I(1). Dan jika variabel dengan Integrated-order yang berbeda $(\mathrm{I}(1,0, \ldots)$.$) , kombinasi variabel akan$ 
memiliki urutan integrasi sama dengan yang terbesar. Oleh karena itu, kombinasi dari varibel pada penelitian ini semuanya integrated of order one dan layak untuk dilakukan Johansen Test.

\section{Pengujian Secara Multivariat}

Selanjutnya, Johansen Test dilakukan dengan bantuan program Eviews untuk mendapatan nilai Maximum Eigenvalue dan Trace Statistic. Nilai maximum eigenvalue dan trace statistic yang lebih kecil dari nilai critical value nya mengindikasikan tidak adanya kointegrasi. Johansen Test yang pertama dilakukan pada pasar modal Indonesia, Malaysia dan Singapura secara bersamaan.

Berdasarkan hasil uji ini, maximum eigenvalue lebih kecil dari critical value. Begitu juga dengan nilai trace statistic juga menunjukkan angka yang lebih rendah dari critical value nya. Oleh karena itu, kointegrasi tidak ada antara pasar modal Indonesia, Malaysia dan Singapura. Hasil Temuan ini sejalan dengan temuan dari penelitian kointegrasi saham oleh Tabak dan Lima (2003) di Amerika Latin, Yang et al (2003) terhadap kointegrasi US dan pasar emerging, Million \& Arauri (2009), serta Musnadi et al (2018).

\section{Pengujian Secara Bivariat \\ Pasar Modal Indonesia dan Malaysia}

Tidak ditemukan kointegrasi antara pasar modal Indonesia dan Malaysia. Dalam jangka panjang kedua pasar tersebut tidak saling berasosiasi. Tabel 3 dan 4 berikut menunjukkan hasil Uji Johansen terhadap kedua pasar modal tersebut:

Tabel 3. Trace Statistics

\begin{tabular}{lcccc}
\hline $\begin{array}{c}\text { Hyphotesize } \\
\text { d number of } \\
\text { CE }(\mathrm{s})\end{array}$ & $\begin{array}{c}\text { Eigen } \\
\text { Value }\end{array}$ & $\begin{array}{c}\text { Trace } \\
\text { Statistics }\end{array}$ & $\begin{array}{c}0,05 \\
\text { Critical } \\
\text { Value }\end{array}$ & Prob \\
\hline None & 0,031122 & 11,63698 & 15,49471 & 0,1752 \\
At most 1 & 0,006269 & 1,930784 & 3,841466 & 0,1647 \\
\hline
\end{tabular}

Sumber: Diolah
Tabel 4. Max-Eigen Value

\begin{tabular}{lcccc}
\hline $\begin{array}{c}\text { Hyphotesize } \\
\text { d number of } \\
\text { CE }(\mathrm{s})\end{array}$ & $\begin{array}{c}\text { Eigen } \\
\text { Value }\end{array}$ & $\begin{array}{c}\text { Max- } \\
\text { eigen } \\
\text { statistic }\end{array}$ & $\begin{array}{c}\text { Critical } \\
\text { Value }\end{array}$ & Prob \\
\hline None & 0,031122 & 9,706195 & 14,24460 & 0,2319 \\
At most 1 & 0,006269 & 1,930784 & 3,841466 & 0,1647 \\
\hline \multicolumn{4}{l}{ Sumber: Diolah }
\end{tabular}

Dalam pengujian Johansen dengan dua variabel akan menghasilkan satu persamaan kointegrasi, tabel 3 menunjukkan ada 2 hipotesis: 1) tidak ada kointegrasi antara variabel, 2) paling tidak ada satu persamaan kointegrasi. Berdasarkan hasil pengujian hipotesis pertama tidak bisa ditolak yaitu kedua variabel tidak memiliki kointegrasi (None). Hal ini dikarenakan nilai trace statistics < dari critical value. Begitu juga dengan Max-eigen value juga lebih kecil dari critical value pada level $5 \%$.

\section{Pasar Modal Indonesia dan Singapura}

Pasar Modal Indonesia dan Singapura juga tidak menunjukkan adanya hubungan jangka panjang. Hal ini dapat dilihat dari hasil uji kointegrasi yang disajikan dalam tabel 5 dan 6 di bawah ini:

\section{Tabel 5. Trace Statistics}

\begin{tabular}{lcccc}
\hline $\begin{array}{c}\text { Hyphotesize } \\
\text { d number of } \\
\text { CE }(\mathrm{s})\end{array}$ & $\begin{array}{c}\text { Eigen } \\
\text { value }\end{array}$ & $\begin{array}{c}\text { Trace } \\
\text { Statistics }\end{array}$ & $\begin{array}{c}0,05 \\
\text { Critical } \\
\text { Value }\end{array}$ & Prob \\
\hline None & 0,017779 & 10,21405 & 15,49471 & 0,2646 \\
At most 1 & 0,015215 & 4,706849 & 3,841466 & 0,0300 \\
\hline \multicolumn{4}{l}{ Sumber: Diolah }
\end{tabular}

Tabel 6. Max-Eigen Value

\begin{tabular}{|c|c|c|c|c|}
\hline $\begin{array}{l}\text { Hyphotesized } \\
\text { number of } \\
\text { CE }(\mathrm{s})\end{array}$ & Eigenvalue & $\begin{array}{l}\text { Max- } \\
\text { eigen } \\
\text { statistic }\end{array}$ & $\begin{array}{c}0,05 \\
\text { Critical } \\
\text { Value }\end{array}$ & Prob \\
\hline None & 0,017779 & 5,507199 & 14,25460 & 0,6769 \\
\hline At most 1 & 0,015215 & 4,706849 & 3,841466 & 0,0300 \\
\hline
\end{tabular}

Dari hasil tabel 5 dan 6 diatas dapat kita lihat bahwa hipotesis yang menyatakan tidak ada kointegrasi antara kedua pasar modal tidak dapat ditolak dikarenakan $p$ value lebih besar dari 5\%. Yang menarik dari hasil tabel 5 dan 6 adalah pada hipotesis at most one cointegration menunjukkan adanya kointegrasi dikarenakan nilai trace statistics dan max-eigen statistics lebih besar dari 
critical value, namun sayang nya p-value memberikan hasil yang signifikan untuk menolak hipotesis ini. Oleh karena itu, kesimpulan yang dapat diambil adalah pasar modal Indonesia dan Singapura tidak terkointegrasi.

\section{Pasar Modal Malaysia dan Singapura}

Berdasar tabel 7 dan 8, ditemukan adanya bukti kointegrasi antara pasar modal Malaysia dan Singapura. Dari hasil pengujian nilai $p$-value dibawah 5\% sehingga hipotesis tidak adanya kointegrasi dapat ditolak. Pengujian bivariat melibatkan 2 pasar modal atau variabel. Dalam analisis kointegrasi yang melibatkan 2 variabel kemungkinan hanya memiliki satu hubungan jangka panjang (n-1).

Tabel 7. Trace Statistics

\begin{tabular}{lcccc}
\hline $\begin{array}{c}\text { Hyphotesize } \\
\text { dnumber of }\end{array}$ & $\begin{array}{c}\text { Eigen } \\
\text { Value }\end{array}$ & $\begin{array}{c}\text { Trace } \\
\text { Statistic }\end{array}$ & $\begin{array}{c}0,05 \\
\text { Critical } \\
\text { Value }\end{array}$ & Prob \\
\hline None & 0,046384 & 17,93687 & 15,49471 & 0,0210 \\
At most 1 & 0,010872 & 3,356132 & 3,841466 & 0,0670 \\
\hline \multicolumn{4}{l}{ Sumber: Diolah }
\end{tabular}

Tabel 8. Max-Eigen Value

\begin{tabular}{ccccc}
\hline $\begin{array}{c}\text { Hyphotesize } \\
\text { dnumber of } \\
\text { CE }(\mathrm{s})\end{array}$ & $\begin{array}{c}\text { Eigen } \\
\text { Value }\end{array}$ & $\begin{array}{c}\text { Max- } \\
\text { eigen } \\
\text { statistic }\end{array}$ & $\begin{array}{c}\text { O,05 } \\
\text { Critical } \\
\text { Value }\end{array}$ & Prob \\
\hline None & 0,046384 & 14,58074 & 14,26460 & 0,0446 \\
At most 1 & 0,010872 & 3,356132 & 3,841466 & 0,0670 \\
\hline \multicolumn{4}{l}{ Sumber: Diolah }
\end{tabular}

Hipotesis adanya satu hubungan kointegrasi menunjukkan nilai $p$-value diatas 5\% sehingga hipotesis ini tidak bisa ditolak. Hasil ini juga di dukung oleh nilai trace statistics dan max-eigen statistics yang lebih besar dari critical value-nya, yang merupakan syarat kedua variabel dikatakan memiliki kointegrasi.

\section{Kesimpulan}

Hasil penelitian ini menunjukkan secara multivariat tiga pasar modal tersebut tidak menunjukkan adanya hubungan jangka panjang. Pengujian multivariat tidak selamanya didukung oleh hasil pengujian secara berpasangan. Kebaharuan penelitian ini menunjukkan bahwa pengujian yang lebih spesifik antara dua pasar modal saja akan memberikan hasil yang lebih fokus, sehingga mudah dipahami dan diinterprestasikan oleh investor terkait peluang diversifikasi yang tercipta antara dua pasar modal yang diuji, dibandingkan penelitian terdahulu yang menunjukkan hasil yang cenderung sama antara analisis secara pair-case dan multivariate. Secara umum, multivariate testing menunjukkan tidak adanya asosiasi jangka panjang, begitu pula pengujian bivarian antara pasar modal Indonesia dan Malaysia serta Indonesia dan Singapura, namun hasil yang berbeda ditemukan pada pengujian bivariat antara pasar modal Singapura dan Malaysia, dimana kedua pasar modal ini menunjukkan hubungan jangka panjang atau kointegrasi.

\section{DAFTAR PUSTAKA}

Assidenou, K E. (2011) Cointegration of Major Stock Market Indices during the 2008 Global Financial Distress. International Journal of Economics and Finance. 3(2),212-222. http://www.ccsenet.org/journal/index. php/ijef/article/view/7451

Bhuvaneshwari, D \& Ramya, K. (2017) Cointegration and Causality between Stock Prices and Exchange Rate: Empirical Evidence from India. SDMIMD Journal of Management. 8(1), 31-38.

https://www.researchgate.net/publicat ion/317798202_Cointegration_and_C ausality_between_Stock_Prices_and_ Exchange_Rate_Empirical_Evidence _from_India

Brooks, Chris (2008) Introduction Economitrics for Finance. New York. Cambridge University Press.

https://www.cambridge.org/es/acade mic/textbooks/introductoryeconometrics

Climent, F.J \& Meneu V. (2003). Has 1997Asian Crisis Increased Information Flows between International Markets? International Review of Economics and Finance. 12,111-143. 
https://www.researchgate.net/publicat ion/223509718_Has_1997_Asian_cri sis_increased_information_flows_bet ween_international_markets

Claire G. Gilmore \& Ginette M. McManus. (2002) International Portfolio Diversification: US and Central European Equity Markets. Emerging Markets Review.3(1), 69-83

https://www.researchgate.net/publicat ion/222214527_International_Portfoli o_Diversification_US_and_Central_ European_Equity_Markets

Clare, A.D Maras, M \& Thomas, S.H. (1995) The Integration and Efficiency of International Bond Market. Journal of Business Finance. 22(2), 313-322.

https://www.researchgate.net/publicat ion/228049019_The_Integration_and _Efficiency_of_International_Bond_ Markets

Danupranata, G. (2003). Pergerakan Bersama (Comovement) Indeks Harga Saham Antar Sektor Industri Di Bursa Efek Jakarta Dengan Menggunakan Pendekatan Statistik Non Parametrik Tahun 1998-2002. Jurnal Keuangan, $1-25$.

https://studylibid.com/doc/629325/pe rgerakan-bersama--comovement-pasar-saham-antar

Ibrahim, M \& Mussah, A. (2014) Causality and Cointegration Analysis: Evidence from the Brazilian Stock Market. European Journal of Business and Management. 6(3),130-142.

https://iiste.org/Journals/index.php/EJ BM/article/view/10534

Introvigne, S. Bacchiocchi ,E. Vandone,D. (2017) A Cointegration Analysis of Wine Stock Indexes. Risk Governance and Control: Financial Markets \& Institutions.7( 4), 178-188.

https://pdfs.semanticscholar.org/a464 /bd2fffd8f759f1240186b26135f6b23f 7 aff.pdf

Lanouar, C., Najah, A., \& Teulon, F. (2016). Socially Responsibility Investing and Islamic Fund: New Perspective for Portolio Allocation. Reasearch in
International Business and Finance, 351-361.

https://www.sciencedirect.com/scienc e/article/abs/pii/S0275531915300374

Mills, T. C. \& Mills, A. G. (1991) The International Transmission of Bond Market Movements, Bulletin of Economic Research 43,.273-82. https://onlinelibrary.wiley.com/doi/ab s/10.1111/j.14678586.1991.tb00496.x

Muhajir, H.M (2008) Analisis Kointegrasi: Keterkaitan Jakarta Islamic Indeks Dengan IHSG dan SBI di Bursa Efek Jakarta.

https://www.researchgate.net/publicat ion/277995772_ANALISIS_KOINT EGRASI_KETERKAITAN_JAKAR TA_ISLAMIC_INDEKS_DENGAN _IHSG_DAN_SBI_DI_BURSA_EFE K_JAKARTA_Periode_April_2005_ -_Juli_2007

Musnadi, Said. Zuraida. Irmalis, A. (2018) Cointegration Analysis of Industrial Sectors on the Indonesia Stock Exchange: A Multivariate Approach. Proceeding of The $136^{\text {th }}$ International IRES Conference.

http://www.worldresearchlibrary.org/ up_proc/pdf/1817-15388067342933.pdf

Puspitasari,A. Siregar,H \& Andati,T. (2015) Analisi Integrasi Bursa Saham ASEAN 5. Jurnal Ekonomi dan Kebijakan Pembangunan. 4(22), 187 206.

https://journal.ipb.ac.id/index.php/jek p/article/view/19807/0

Quang, V.T. (2007) Testing Cointegration for Czech Stock Market. Acta Oeconomica Pragensia, 15( 4),17-31. https://aop.vse.cz/pdfs/aop/2007/04/0 2.pdf

Robert-jan Gerrits \& Ayse Yuce (1999) Short- and Long-Term Links among European and US stock markets, Applied Financial Economics, 9:1 https://ideas.repec.org/a/taf/apfiec/v9 y1999i1p1-9.html 
Walid, M.A. Ahmed, (2012) On The Interdependence Structure of Market Sector Indices: The Case of Qatar Exchange. Review of Accounting and Finance. 11 (4),468-488.

https://www.emerald.com/insight/con tent/doi/10.1108/1475770121127920 4/full/html

Yang, C, Chen, Y, Niu, L, Li, Q.(2014) Cointegration Analysis and Influence Rank - A Network Approach to Global Stock markets. Physica A 400 (2014). 168-185.

https://www.sciencedirect.com/scienc e/article/pii/S0378437114000156 